\title{
Effects of yeast hydrolysate supplementation on intestinal morphology, barrier, and anti-inflammatory functions of broilers
}

\author{
Ting Wang ${ }^{1}$, Kang Cheng ${ }^{1}$, QiMing $\mathrm{Li}^{1}$, and Tian Wang ${ }^{1{ }^{1 *}}$
}

\author{
* Corresponding Author: Tian Wang \\ Tel: +86-025-84396483, \\ Fax: +86-025-84395156 \\ E-mail: tianwangnjau@163.com
}

${ }^{1}$ College of Animal Science and Technology, Nanjing Agricultural University, Nanjing, Jiangsu 210095, China

ORCID

Ting Wang

https://orcid.org/0000-0003-2999-8436

Kang Cheng

https://orcid.org/0000-0002-7645-7811

QiMing Li

https://orcid.org/0000-0001-7077-881X

Tian Wang

https://orcid.org/0000-0002-9038-5009

Submitted Aug 19, 2021; Revised Oct 6, 2021; Accepted Nov 16, 2021
Objective: This study was conducted to evaluate the effects of dietary yeast hydrolysate (YH) supplementation on intestinal morphology, barrier, and anti-inflammatory functions of broilers.

Methods: A total of 320 one day old male broilers were randomly allocated into four groups with eight replicates of ten broilers each. The broilers were supplemented with a basal diet (the control group) or basal diets adding 50, 100, $150 \mathrm{mg} / \mathrm{kg} \mathrm{YH}$, respectively. This trial lasted for 42 days. The orthogonal polynomial contrasts were used to determine the linear and quadratic effects of increasing levels of $\mathrm{YH}$.

Results: In our previous research, supplementing YH improved growth performance by enhancing body weight gain but decreased feed-to-gain ratio. In this study, compared with the control group, dietary $\mathrm{YH}$ addition linearly and quadratically decreased serum diamine oxidase activity $(\mathrm{p}<0.05)$. Additionally, supplementing $\mathrm{YH}$ linearly and/or quadratically decreased jejunal crypt depth (CD), tumor necrosis factor-alpha (TNF- $\alpha$ ) concentration as well as mucin 2, interleukin-6 (IL-6), IL-1 $\beta$, TNF- $\alpha$, nuclear factor kappa B, and myeloid differentiation factor 88 gene expression levels $(\mathrm{p}<0.05)$. Whereas the jejunal villus height (VH), VH/CD, IL-10 concentration as well as zonula occludens-1 and IL-10 gene expression levels were linearly and/or quadratically increased by YH supplementation $(\mathrm{p}<0.05)$.

Conclusion: Dietary YH supplementation improved intestinal morphology, barrier and anti-inflammatory functions while decreased intestinal permeability of broilers, which might be related with altering pertinent genes expression. This study provides evidence of $\mathrm{YH}$ as a promising feed additive for broilers.

Keywords: Anti-inflammation; Broiler; Intestinal Barrier; Intestinal Morphology; Yeast Hydrolysate

\section{INTRODUCTION}

Small intestine, as the barrier between the body and external environment, is easily affected or even damaged by various adverse factors including feed toxin, pathogenic bacteria, invasive viruses, high temperature and unsanitary feeding conditions. A well-developed intestinal mucosa and barrier integrity are beneficial to decrease intestinal permeability and defend against external disadvantages, thus maintaining the health of the intestine and improving growth performance of animals [1,2]. Dietary manipulation is an effectual way of shaping intestinal mucosal development and barrier function [2]. Thus, it is essential to improve intestinal barrier integrity and anti-inflammatory function though nutritional efforts, thus improving intestinal health status and growth performance, which is of great significance for poultry production.

Various yeast-derived products including yeast culture, yeast extracts, yeast hydrolysate $(\mathrm{YH})$ and yeast cell wall, are natural feed additives which have been applied in animal production for many years [3-9]. Dietary supplementation with whole yeast and yeast cell 
wall showed positive effects on pancreatic enzyme activities and ileal protein digestibility, thus improving growth performance and meat yield of broiler chickens [10]. Bilal et al [11] indicated that yeast-based additives could improve humoral immunity by increasing serum immunoglobulin A level. Besides, yeast additives are probably supportive of immune hemostasis though medicating the balance between proand anti-inflammatory activities. Recent studies have found that yeast cell wall addition to feed improved serum immune response as well as intestinal integrity and immune function of animals $[8,12]$. Moreover, fractions or extracts of yeast cell wall including $\beta$-glucan and mannan-oligosaccharide (MOS) could improve intestinal barrier, anti-inflammatory and immune functions as well as regulate the microflora in the hindgut in different animals [13-15].

Yeast hydrolysate is derived from Saccharomyces cerevisiae, which has a lower cost advantage compared with other extracted yeast additives [7]. Fu et al [16] demonstrated that supplementing YHs enhanced growth performance, serum immune cytokines levels and beneficial bacteria in the cecum of growing-finishing pigs. Also, dietary brewer's $\mathrm{YH}$ addition improved growth performance and the digestibility of nutrients in growing pigs [7]. In addition, supplementing YH increased antioxidant capacity as well as disease resistance and non-specific immunity in aquatic animals $[17,18]$. It follows that the application of $\mathrm{YH}$ in animal production has great value and potential. However, the existing literature on YH has mainly studied ruminants, pigs or aquatic animals, little information is available regarding the effects of YH supplementation in broilers, especially in terms of intestinal development and health. According to our previous study, we have found that YH supplementation had beneficial effects on growth performance, intestinal antioxidant, and immune functions of broilers [19,20]. To explore further, this study aimed to evaluate different levels of YH addition on intestinal morphology, barrier, and anti-inflammatory functions of broilers, which might provide evidence for the scientific application of YH in broilers production.

\section{MATERIALS AND METHODS}

All experimental design and procedures were supervised by Institutional Animal Care and Use Committee of Nanjing Agricultural University following the requirements of the Regulations for the Administration of Affairs Concerning Experimental Animals of China (NJAU-CAST-2017-019).

\section{Experimental design and animal management}

A total of 320 male one-day-old Arbor Acres broiler chicks (average body weight, $39.50 \pm 0.30 \mathrm{~g}$ ) were purchased from a commercial hatchery (Yantai Land Animal Husbandry Co. Ltd., Shandong, China) and randomly assigned into four treatments for a 42-d feeding trial. Each treatment had eight replicates and each replicate had ten birds. Birds in the control group (CON) were provided with a basal diet, and the other three groups were fed the basal diet with the addition of 50,100 , and $150 \mathrm{mg} / \mathrm{kg} \mathrm{YH}$ respectively. The YH was obtained from Church \& Dwight Co., Inc. (Princeton, NJ, USA), which is a complex product derived from enzymatic hydrolysis of the yeast and mainly composed of crude protein $(>30 \%)$, functional polysaccharides (MOS $>6 \%$; $\beta$-glucan $>8 \%$ ), yeast culture and nucleotides. All diets were formulated to satisfy or exceed the nutritional requirements according to the National Research Council (1994) [21]. The composition and nutrition levels of all diets are presented in Table 1. All broiler chickens were raised in three-level cages ( 120 $\times 60 \times 50 \mathrm{~cm})$ and given free access to feed and water. The environmental temperature in the house was controlled ranged from $34^{\circ} \mathrm{C}$ to $36^{\circ} \mathrm{C}$ during 1 to $7 \mathrm{~d}$ and subsequently declined to a final temperature of $24^{\circ} \mathrm{C}$ until the end of the experiment.

\section{Sampling}

On $21 \mathrm{~d}$ and $42 \mathrm{~d}$, eight birds (one bird per pen) from each group were randomly selected after a 12 -h feed deprivation. Heparinized blood collected from the wing vein was cen-

Table 1. Composition and nutrient content of the basal diet (as fed basis)

\begin{tabular}{|c|c|c|}
\hline Item & 1 to $21 \mathrm{~d}$ & 22 to $42 \mathrm{~d}$ \\
\hline \multicolumn{3}{|l|}{ Ingredient (\%) } \\
\hline Corn & 55.60 & 55.20 \\
\hline Soybean meal (44\%, crude protein) & 29.00 & 24.00 \\
\hline Cottonseed meal (44\%, crude protein) & 2.50 & 3.00 \\
\hline Wheat flour & 4.00 & 4.00 \\
\hline hydrolyzed feather meal & 1.50 & 1.50 \\
\hline Dicalcium phosphate & 0.90 & 0.80 \\
\hline Limestone & 1.50 & 1.50 \\
\hline Amargosite & 1.00 & 1.00 \\
\hline Soybean oil & 2.00 & 7.00 \\
\hline Premix ${ }^{1)}$ & 2.00 & 2.00 \\
\hline \multicolumn{3}{|l|}{ Calculated nutrient levels } \\
\hline Metabolisable energy (MJ/kg) & 12.46 & 13.38 \\
\hline Crude protein (\%) & 21.50 & 19.51 \\
\hline Calcium (\%) & 0.96 & 0.84 \\
\hline Total phosphorus (\%) & 0.66 & 0.55 \\
\hline Lysine (\%) & 1.45 & 1.40 \\
\hline Methionine (\%) & 0.54 & 0.50 \\
\hline Threonine (\%) & 0.91 & 0.80 \\
\hline \multicolumn{3}{|c|}{ 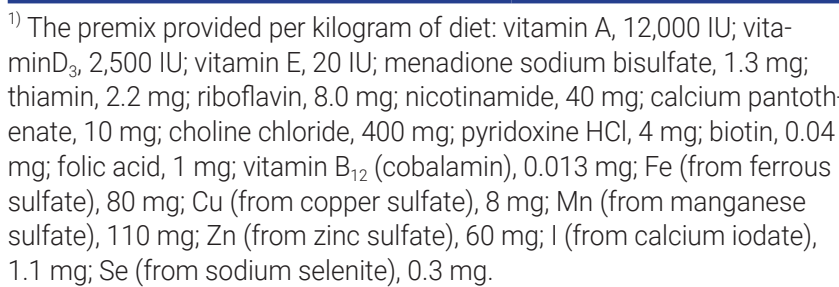 } \\
\hline
\end{tabular}


trifuged at $4,000 \times \mathrm{g}$ for $15 \mathrm{~min}$ at $4^{\circ} \mathrm{C}$ to collect top serum samples, which were then stored at $-80^{\circ} \mathrm{C}$ until analysis. After blood collection, birds were euthanized by cervical dislocation and necropsied. The jejunal tissues were rapidly collected and the jejunal sections about $2 \mathrm{~cm}$ in length were sliced at the middle position and fixed in chilled 4\% paraformaldehyde for morphometric evaluation. The remaining jejunum segments were opened longitudinally at the same position and flushed the residual digesta with ice-cold phosphate buffer solution to collect mucosal samples. The jejunal mucosa was collected by directly scraping using a sterile glass microscope slide at $4^{\circ} \mathrm{C}$, which were then immediately frozen in liquid nitrogen and stored at $-80^{\circ} \mathrm{C}$ until analysis.

\section{Determination of serum diamine oxidase activity}

The serum diamine oxidase (DAO) activity was determined by a commercial diagnostic kit purchased from Nanjing Angle Gene (Jiangsu Province, China). The experimental operations were strictly complied with the instructions of the manufacturer.

\section{Determination of jejunal morphology}

The specimens of the jejunal tissues were first fixed in a paraformaldehyde solution for $24 \mathrm{~h}$ at room temperature. After that, they were dehydrated through an upgraded series of ethanol and xylene soaking, and then were embedded in paraffin blocks. Cross sections of the tissue segments were sliced at a thickness of $5 \mu \mathrm{m}$ and stained with hematoxylin and eosin. The villus height $(\mathrm{VH}$, from the tip of villus to the villus-crypt junction level for 10 villi per section) and crypt depth (CD, the vertical distance from the villus-crypt junction to the lower limit of the crypt for 10 corresponding crypts per section) were measured using a light microscope equipped with a computer-assisted morphometric system (Nikon Corporation, Tokyo, Japan). The ratio between VH and CD was also calculated (VH/CD).

\section{Determination of jejunal inflammatory cytokines}

About $1 \mathrm{~g}$ jejunal mucosal samples were cut off and added with ice-cold sodium chloride solution $(154 \mathrm{mmol} / \mathrm{L})$, then homogenized (1:4, wt/vol) using an ultraturrax homogenizer (Tekmar Co., Cinatti, OH, USA). Afterwards, the above homogenate was centrifuged at $4,000 \times g$ for $15 \mathrm{~min}$ at $4^{\circ} \mathrm{C}$. The top supernatant was promptly collected and used for assaying jejunal mucosal inflammatory cytokines.

The chicken-specific enzyme-linked immuno sorbent assay quantification kits (Angle Gene, Nanjing, China) were used to measure the concentrations of tumor necrosis factor $\alpha$ (TNF- $\alpha$ ) and interleukin 10 (IL-10) in the jejunal mucosal samples based on the manufacturer's instructions. The total protein level of each sample was measured by Coomassie brilliant blue protein assay kit (Nanjing Jiancheng Bioengi- neering Institute, Nanjing, Jiangsu, China). The obtained results were normalized against total protein concentration in each sample for inter-sample comparison.

\section{Determination of jejunal gene expression levels}

Total RNA was extracted from the jejunal mucosa in line with the instructions of manufacturer using Trizol Reagent (Vazyme Biotech Co., Ltd, Nanjing, China). The RNA concentration and purity were determined using a NanoDrop ND-1000 UV spectrophotometer (NanoDrop Technologies, Wilmington, DE, USA). After that, $1 \mu \mathrm{g}$ of total RNA was reverse-transcribed into complementary DNA though a process including $15 \mathrm{~min}$ at $37^{\circ} \mathrm{C}$ and $5 \mathrm{~s}$ at $85^{\circ} \mathrm{C}$ by PrimeScript RT reagent kit (Vazyme Biotech Co., Ltd, China) following its protocols. The complementary DNA samples were amplified with the ChamQ SYBR qPCR Master Mix Kit (Vazyme Biotech Co., Ltd, China) according to the manufacturer's requirement. Real-time polymerase chain reaction (PCR) was carried out on a QuantStudio 5real-time PCR Design \& Analysis system (Applied Biosystems, Carlsbad, CA, USA). The process of PCR was consisted of a pre-run at $95^{\circ} \mathrm{C}$ for $30 \mathrm{~s}, 40$ cycles of denaturation at $95^{\circ} \mathrm{C}$ for $5 \mathrm{~s}$, an annealing step at $60^{\circ} \mathrm{C}$ for $30 \mathrm{~s}$ and the melt-curve stage $\left(95^{\circ} \mathrm{C}\right.$ for $15 \mathrm{~s}$, $60^{\circ} \mathrm{C}$ for $1 \mathrm{~min}$ and $95^{\circ} \mathrm{C}$ for $15 \mathrm{~s}$ ). The standard curve of each gene was run in duplicate and three times for obtaining reliable amplification efficiency. The relative levels of mRNA expression were calculated using $2^{-\Delta \Delta C t}$ method after normalization against the reference gene, $\beta$-actin [22]. The values of the CON group were used as a calibrator. All primers were synthesized by Sangon Biotech Co., Ltd. (Shanghai, China) and the sequences were showed in Table 2.

\section{Statistical analysis}

All obtained data were processed by Excel 2010 first, and then analyzed by one-way ANOVA procedure using Statistical Analysis System (SAS Institute, 2000) [23] followed by a Duncan's multiple range test. An individual broiler from each replicate was regarded as the experimental unit for measured indicators. The orthogonal polynomial contrasts were used to determine the linear and quadratic effects of increasing levels of YH. Data were presented as means and their pooled standard errors. The differences were considered as statistically significant when $\mathrm{p}<0.05$.

\section{RESULTS}

\section{Growth performance}

Our previous study has showed that dietary $\mathrm{YH}$ addition linearly and quadratically increased (linear and quadratic, $\mathrm{p}<0.05)$ the body weight gain and gain-to-feed ratio during the starter ( 1 to $21 \mathrm{~d}$ ), growth ( 22 to $42 \mathrm{~d}$ ), and overall (1 to $42 \mathrm{~d}$ ) periods of broilers [20]. 
Table 2. Primer sequences used for the real-time polymerase chain reaction analysis

\begin{tabular}{|c|c|c|c|}
\hline Gene & Genbank number & Primer sequences $\left(5^{\prime}-3^{\prime}\right)$ & Product size (bp) \\
\hline \multirow[t]{2}{*}{$\beta$-actin } & NM_205518.1 & Forward: TTGGTTTGTCAAGCAAGCGG & 100 \\
\hline & & Reverse: CCCCCACATACTGGCACTTT & \\
\hline \multirow[t]{2}{*}{ IL-6 } & NM_204628.1 & Forward: AGGGCCGTTCGCTATTTGAA & 72 \\
\hline & & Reverse: CAGAGGATTGTGCCCGAACT & \\
\hline \multirow[t]{2}{*}{ IL-10 } & NM_001004414.2 & Forward: GGAGCTGAGGGTGAAGTTTGA & 129 \\
\hline & & Reverse: GACACAGACTGGCAGCCAAA & \\
\hline \multirow[t]{2}{*}{$I L-7 \beta$} & NM_204524.1 & Forward: GTACCGAGTACAACCCCTGC & 112 \\
\hline & & Reverse: AGCAACGGGACGGTAATGAA & \\
\hline \multirow[t]{2}{*}{ TNF-a } & JN_942589 & Forward: AGACCAGATGGGAAGGGAATGAA & 219 \\
\hline & & Reverse: GAAGAGGCCACCACACGACAG & \\
\hline \multirow[t]{2}{*}{ IFN-Y } & NM_205149.1 & Forward: CACTGACAAGTCAAAGCCGC & 87 \\
\hline & & Reverse: ACCTTCTTCACGCCATCAGG & \\
\hline \multirow[t]{2}{*}{ TLR4 } & NM_001030693.1 & Forward: AGGCACCTGAGCTTTTCCTC & 96 \\
\hline & & Reverse: TACCAACGTGAGGTTGAGCC & \\
\hline \multirow[t]{2}{*}{$N F-k B$} & NM_205129.1 & Forward: GTGTGAAGAAACGGGAACTG & 203 \\
\hline & & Reverse: GGCACGGTTGTCATAGATGG & \\
\hline \multirow[t]{2}{*}{ MyD88 } & NM_001030962.1 & Forward: ATCCGGACACTAGAGGGAGG & 115 \\
\hline & & Reverse: GGCAGAGCTCAGTGTCCATT & \\
\hline \multirow[t]{2}{*}{ OCLN } & NM_205128.1 & Forward: CCGTAACCCCGAGTTGGAT & 214 \\
\hline & & Reverse: ATTGAGGCGGTCGTTGATG & \\
\hline \multirow[t]{2}{*}{ ZO-1 } & XM_413773.4 & Forward: TGTAGCCACAGCAAGAGGTG & 159 \\
\hline & & Reverse: CTGGAATGGCTCCTTGTGGT & \\
\hline \multirow[t]{2}{*}{ MUC2 } & XM_001234581.3 & Forward: AGGAATGGGCTGCAAGAGAC & 77 \\
\hline & & Reverse: GTGACATCAGGGCACACAGA & \\
\hline \multirow[t]{2}{*}{ CLDN2 } & NM_001277622.1 & Forward: CСTGCTCACССTCATTGGAG & 145 \\
\hline & & Reverse: GCTGAACTCACTCTTGGGCT & \\
\hline
\end{tabular}

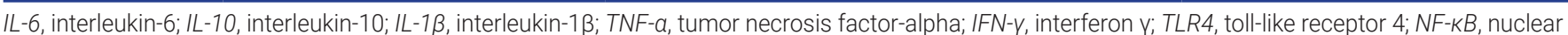
factor kappa B; MyD88, myeloid differentiation factor 88; OCLN, occludin; ZO-1, zonula occludens-1; MUC2, mucin 2; CLDN2, claudin 2.

\section{Serum DAO activity}

According to Table 3, supplementing YH, irrespective of its level, decreased (linear and quadratic, $\mathrm{p}<0.05$ ) serum DAO activity of broilers on $42 \mathrm{~d}$ of age in comparison with the CON group.

\section{Jejunal morphology}

The results of jejunal morphology are shown in Table 4. Dietary YH supplementation linearly and quadratically increased $(\mathrm{p}<0.05)$ jejunal VH/CD on $21 \mathrm{~d}, \mathrm{VH}$ and VH/CD on $42 \mathrm{~d}$ but decreased $(\mathrm{p}<0.05)$ jejunal CD on $21 \mathrm{~d}$. Moreover, jejunal
$\mathrm{CD}$ showed a linear reduction on $42 \mathrm{~d}(\mathrm{p}<0.05)$. The highest $\mathrm{VH}$ and $\mathrm{VH} / \mathrm{CD}$ values as well as lowest $\mathrm{CD}$ value both on $21 \mathrm{~d}$ and $42 \mathrm{~d}$ were observed in $\mathrm{YH} 2$ group.

\section{Jejunal inflammatory cytokines}

In Table 5, compared with the CON group, the increased jejunal IL-10 concentration both on $21 \mathrm{~d}$ and $42 \mathrm{~d}$ was observed in $\mathrm{YH} 2$ and $\mathrm{YH} 3$ groups (linear and quadratic, $\mathrm{p}<0.05$ ). Besides, jejunal TNF- $\alpha$ content was linearly decreased $(\mathrm{p}<0.05)$ on $21 \mathrm{~d}$ and quadratically reduced $(\mathrm{p}<0.05)$ on $42 \mathrm{~d}$ by $\mathrm{YH}$ supplementation.

Table 3. Effects of yeast hydrolysate on serum diamine oxidase activity of broilers

\begin{tabular}{|c|c|c|c|c|c|c|c|}
\hline \multirow{2}{*}{ Item } & \multicolumn{4}{|c|}{ Dietary treatment ${ }^{1)}$} & \multirow{2}{*}{ SEM $^{2)}$} & \multicolumn{2}{|c|}{ p-value } \\
\hline & CON & YH1 & YH2 & YH3 & & Linear & Quadratic \\
\hline \multicolumn{8}{|l|}{$21 \mathrm{~d}$} \\
\hline $\mathrm{DAO}(\mathrm{U} / \mathrm{L})$ & 39.984 & 37.664 & 35.212 & 39.228 & 1.103 & 0.697 & 0.572 \\
\hline \multicolumn{8}{|l|}{$42 \mathrm{~d}$} \\
\hline DAO (U/L) & $48.598^{b}$ & $40.707^{a}$ & $38.912^{a}$ & $37.234^{\mathrm{a}}$ & 1.018 & 0.011 & 0.002 \\
\hline
\end{tabular}

DAO, diamine oxidase.

1) $\mathrm{CON}$, basal diet; $\mathrm{YH} 1, \mathrm{YH} 2$, and $\mathrm{YH} 3$ group, basal diet adding 50, 100, and $150 \mathrm{mg} / \mathrm{kg} \mathrm{YH}$, respectively.

${ }^{2}$ Standard error of the means $(n=8)$.

a,b Means within the same row with no common superscript differ significantly $(p<0.05)$. 
Table 4. Effects of yeast hydrolysate on jejunal morphology of broilers

\begin{tabular}{|c|c|c|c|c|c|c|c|}
\hline \multirow{2}{*}{ Item } & \multicolumn{4}{|c|}{ Dietary treatment ${ }^{1)}$} & \multirow{2}{*}{ SEM $^{2)}$} & \multicolumn{2}{|c|}{ p-value } \\
\hline & CON & YH1 & YH2 & YH3 & & Linear & Quadratic \\
\hline \multicolumn{8}{|l|}{$21 \mathrm{~d}$} \\
\hline $\mathrm{CD}(\mu \mathrm{m})$ & $98.642^{a}$ & $92.652^{\mathrm{ab}}$ & $84.651^{b}$ & $86.712^{b}$ & 2.265 & 0.002 & 0.004 \\
\hline VH/CD & $7.581^{\mathrm{c}}$ & $7.929^{\mathrm{bc}}$ & $9.362^{\mathrm{a}}$ & $8.981 a^{b}$ & 0.764 & 0.003 & 0.009 \\
\hline \multicolumn{8}{|l|}{$42 \mathrm{~d}$} \\
\hline $\mathrm{CD}(\mu \mathrm{m})$ & $198.641^{\mathrm{ab}}$ & $200.087^{\text {bc }}$ & $188.463^{\mathrm{C}}$ & $190.131^{c}$ & 3.926 & 0.022 & 0.074 \\
\hline $\mathrm{VH} / \mathrm{CD}$ & $7.409^{c}$ & $7.574^{c}$ & $8.692^{a}$ & $8.034^{b}$ & 0.665 & 0.001 & $<0.001$ \\
\hline
\end{tabular}

$\mathrm{VH}$, villus height; $\mathrm{CD}$, crypt depth; $\mathrm{VH} / \mathrm{CD}$, the ratio of villus height to crypt depth.

1) $\mathrm{CON}$, basal diet; $\mathrm{YH} 1, \mathrm{YH} 2$, and $\mathrm{YH} 3$ group, basal diet adding 50, 100, and $150 \mathrm{mg} / \mathrm{kg} \mathrm{YH}$, respectively.

2) Standard error of the means $(n=8)$.

${ }^{a-c}$ Means within the same row with no common superscript differ significantly $(p<0.05)$.

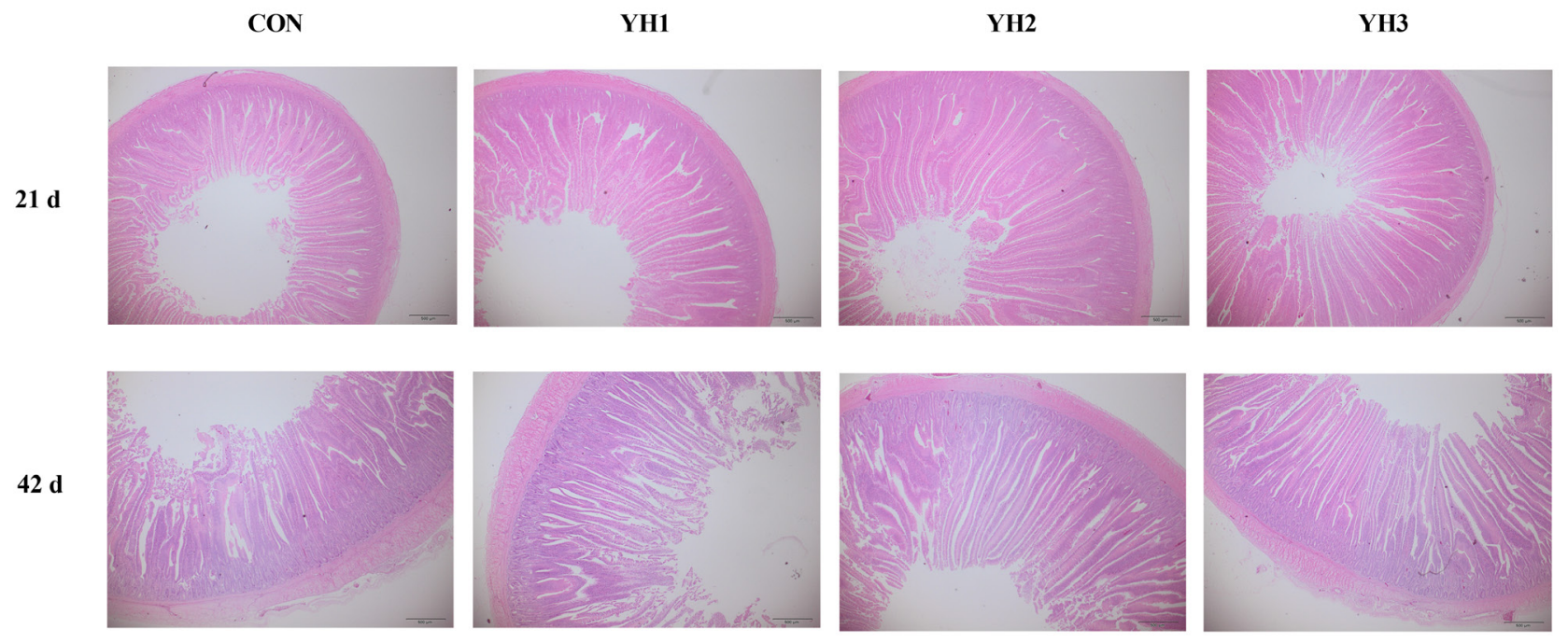

Figure 1. Haematoxylin and eosin (H\&E) staining of jejunum on 21 and 42 days of age of broilers. Scale bar, $500 \mu \mathrm{m}$. CON, basal diet; YH1, YH2, and $\mathrm{YH} 3$ group, basal diet adding 50, 100, and $150 \mathrm{mg} / \mathrm{kg} \mathrm{YH}$, respectively.

\section{Jejunal barrier gene expression levels}

Table 6 indicated that supplementing YH linearly and quadratically decreased $(\mathrm{p}<0.05)$ mucin $2(M U C 2)$ gene expression level whereas enhanced $(\mathrm{p}<0.05)$ zonula occludens-1 $(Z O-1)$ gene expression level in the jejunum both on $21 \mathrm{~d}$ and $42 \mathrm{~d}$ compared with the CON group.

Table 5. Effects of yeast hydrolysate on jejunal inflammatory cytokines of broilers

\begin{tabular}{|c|c|c|c|c|c|c|c|}
\hline \multirow{2}{*}{ Item } & \multicolumn{4}{|c|}{ Dietary treatment ${ }^{1)}$} & \multirow{2}{*}{ SEM $^{2)}$} & \multicolumn{2}{|c|}{$\mathrm{p}$-value } \\
\hline & CON & YH1 & YH2 & YH3 & & Linear & Quadratic \\
\hline \multicolumn{8}{|l|}{$21 \mathrm{~d}$} \\
\hline IL-10 (ng/g protein) & $5.590^{b}$ & $6.507^{\mathrm{ab}}$ & $7.632^{\mathrm{a}}$ & $7.589^{\mathrm{a}}$ & 0.223 & 0.025 & 0.045 \\
\hline TNF-a (ng/g protein) & $9.614^{\mathrm{a}}$ & $8.340^{a b}$ & $8.084^{b}$ & $8.441^{\mathrm{ab}}$ & 0.362 & 0.039 & 0.051 \\
\hline \multicolumn{8}{|l|}{$42 \mathrm{~d}$} \\
\hline IL-10 (ng/g protein) & $5.988^{b}$ & $7.014^{\mathrm{ab}}$ & $7.550^{\mathrm{a}}$ & $7.314^{\mathrm{a}}$ & 0.171 & 0.019 & 0.017 \\
\hline TNF-a (ng/g protein) & $9.445^{\mathrm{a}}$ & $8.799^{\mathrm{ab}}$ & $7.733^{\mathrm{b}}$ & $9.122^{\mathrm{a}}$ & 0.163 & 0.291 & 0.039 \\
\hline
\end{tabular}

IL-10, interleukin-10; TNF-a, tumor necrosis factor-alpha.

1) $\mathrm{CON}$, basal diet; $\mathrm{YH} 1, \mathrm{YH} 2$, and $\mathrm{YH} 3$ group, basal diet adding 50, 100, and $150 \mathrm{mg} / \mathrm{kg} \mathrm{YH}$, respectively.

2) Standard error of the means $(n=8)$.

a,b Means within the same row with no common superscript differ significantly $(p<0.05)$. 
Table 6. Effects of yeast hydrolysate on jejunal barrier genes expression of broilers

\begin{tabular}{|c|c|c|c|c|c|c|c|}
\hline \multirow{2}{*}{ Item } & \multicolumn{4}{|c|}{ Dietary treatment ${ }^{1)}$} & \multirow{2}{*}{ SEM $^{2)}$} & \multicolumn{2}{|c|}{ p-value } \\
\hline & CON & YH1 & YH2 & YH3 & & Linear & Quadratic \\
\hline \multicolumn{8}{|l|}{$21 \mathrm{~d}$} \\
\hline OCLD & 1.000 & 0.968 & 1.009 & 0.986 & 0.044 & 0.996 & 0.998 \\
\hline ZO-1 & $1.000^{\mathrm{a}}$ & $1.513^{b}$ & $1.663^{\mathrm{b}}$ & $1.518^{\mathrm{b}}$ & 0.052 & 0.006 & 0.011 \\
\hline CLDN2 & 1.000 & 1.153 & 1.222 & 1.219 & 0.043 & 0.160 & 0.305 \\
\hline MUC2 & $1.000^{\mathrm{a}}$ & $0.698^{b}$ & $0.585^{b}$ & $0.581^{b}$ & 0.034 & 0.003 & 0.003 \\
\hline OCLD & 1.000 & 0.983 & 0.878 & 0.980 & 0.036 & 0.867 & 0.979 \\
\hline ZO-1 & $1.000^{\mathrm{a}}$ & $1.136^{\mathrm{ab}}$ & $1.321^{b}$ & $1.360^{b}$ & 0.061 & 0.043 & 0.026 \\
\hline CLDN2 & 1.000 & 1.017 & 1.043 & 1.013 & 0.052 & 0.504 & 0.336 \\
\hline
\end{tabular}

MUC2, mucin 2; OCLN, occludin; ZO-1, zonula occludens-1; CLDN2, claudin 2.

1) CON, basal diet; $\mathrm{YH} 1, \mathrm{YH} 2$, and $\mathrm{YH} 3$ group, basal diet adding 50, 100, and $150 \mathrm{mg} / \mathrm{kg} \mathrm{YH}$, respectively.

2) Standard error of the means $(n=8)$.

a,b Means within the same row with no common superscript differ significantly $(p<0.05)$.

Jejunal inflammatory gene expression levels

In Table 7, compared with the CON group, on $21 \mathrm{~d}$ of age, supplementing $\mathrm{YH}$ linearly and quadratically increased $(\mathrm{p}<$ $0.05) I L-10$ gene expression level whereas decreased $(\mathrm{p}<0.05)$ $I L-1 \beta, T N F-\alpha$, and myeloid differentiation factor 88 (MyD88) gene expression levels in the jejunum. On $42 \mathrm{~d}$ of age, jejunal IL-6 and nuclear factor kappa B $(N F-\kappa B)$ gene expression levels were linearly and quadratically decreased $(\mathrm{p}<0.05)$ whereas that of IL-10 showed an opposite result $(p<0.05)$ by
YH supplementation. Besides, jejunal MyD88 gene expression level on $42 \mathrm{~d}$ was quadratically decreased $(\mathrm{p}<0.05)$ by $\mathrm{YH}$ inclusion.

\section{DISCUSSION}

Recent research suggested that diets supplemented with brewer's YH had beneficial effects on growth performance in finishing pigs [7]. Similarly, our previous study had found

Table 7. Effects of yeast hydrolysate on jejunal inflammation-related genes expression of broilers

\begin{tabular}{|c|c|c|c|c|c|c|c|}
\hline \multirow{2}{*}{ Item } & \multicolumn{4}{|c|}{ Dietary treatment ${ }^{1)}$} & \multirow{2}{*}{ SEM $^{2)}$} & \multicolumn{2}{|c|}{ p-value } \\
\hline & CON & YH1 & YH2 & YH3 & & Linear & Quadratic \\
\hline \multicolumn{8}{|l|}{$21 \mathrm{~d}$} \\
\hline IL-6 & 1.000 & 0.762 & 0.735 & 0.887 & 0.061 & 0.497 & 0.204 \\
\hline IL-10 & $1.000^{\mathrm{b}}$ & $1.584^{\mathrm{a}}$ & $2.137^{\mathrm{C}}$ & $1.885^{\mathrm{a}}$ & 0.115 & 0.017 & 0.019 \\
\hline IL-1 $\beta$ & $1.000^{\mathrm{a}}$ & $0.834^{\mathrm{ab}}$ & $0.780^{\mathrm{ab}}$ & $0.603^{b}$ & 0.044 & 0.001 & 0.006 \\
\hline TNF-a & $1.000^{\mathrm{a}}$ & $0.679^{b}$ & $0.527^{c}$ & $0.648^{b}$ & 0.052 & 0.014 & 0.005 \\
\hline IFN-y & 1.000 & 0.968 & 0.988 & 0.903 & 0.055 & 0.611 & 0.852 \\
\hline TLR4 & 1.000 & 1.016 & 0.920 & 0.977 & 0.058 & 0.715 & 0.917 \\
\hline NF-kB & 1.000 & 1.100 & 1.024 & 0.956 & 0.040 & 0.370 & 0.272 \\
\hline MyD88 & $1.000^{\mathrm{a}}$ & $0.736^{\mathrm{ab}}$ & $0.681^{b}$ & $0.640^{\mathrm{b}}$ & 0.045 & 0.005 & 0.016 \\
\hline \multicolumn{8}{|l|}{$42 \mathrm{~d}$} \\
\hline IL-6 & $1.000^{\mathrm{a}}$ & $0.700^{b}$ & $0.534^{b}$ & $0.661^{b}$ & 0.082 & 0.018 & 0.008 \\
\hline $\mathrm{IL}-10$ & $1.000^{\mathrm{a}}$ & $1.195^{\mathrm{ab}}$ & $1.453^{b}$ & $1.637^{b}$ & 0.189 & 0.032 & 0.028 \\
\hline$I L-1 \beta$ & 1.000 & 0.844 & 0.753 & 0.734 & 0.064 & 0.082 & 0.187 \\
\hline TNF-a & 1.000 & 0.969 & 0.879 & 0.806 & 0.049 & 0.131 & 0.319 \\
\hline IFN-y & 1.000 & 0.954 & 0.880 & 1.011 & 0.033 & 0.430 & 0.296 \\
\hline TLR4 & 1.000 & 0.928 & 0.823 & 0.912 & 0.049 & 0.448 & 0.572 \\
\hline NF-kB & $1.000^{\mathrm{a}}$ & $0.912^{\mathrm{ab}}$ & $0.904^{b}$ & $0.826^{b}$ & 0.034 & 0.033 & 0.001 \\
\hline MyD88 & $1.000^{\mathrm{a}}$ & $0.931^{\mathrm{ab}}$ & $0.891^{\mathrm{ab}}$ & $0.799^{b}$ & 0.047 & 0.069 & 0.018 \\
\hline
\end{tabular}

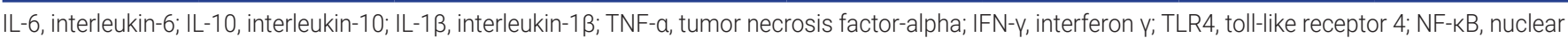
factor kappa B; MyD88, myeloid differentiation factor 88 .

1) $\mathrm{CON}$, basal diet; $\mathrm{YH} 1, \mathrm{YH} 2$, and $\mathrm{YH} 3$ group, basal diet adding 50, 100, and $150 \mathrm{mg} / \mathrm{kg} \mathrm{YH}$, respectively.

${ }^{2}$ Standard error of the means $(n=8)$.

${ }^{a-c}$ Means within the same row with no common superscript differ significantly $(p<0.05)$. 
that YH supplementation could improve the body weight gain but decrease the gain to feed ratio during the starter, grower, and overall period of broilers [20]. The growth performance might be affected by many factors. Referring to our previous study, dietary YH supplementation enhanced intestinal digestive enzyme activities, antioxidant, and immune function of broilers $[19,20]$. Moreover, we could conclude that the positive effects of $\mathrm{YH}$ on growth performance might be also related to the improvement of intestinal morphology, barrier and anti-inflammatory functions of broilers based on this study.

The villus of small intestine is the main site for digestion and absorption in the body. Thus, the health of small intestine is vital to intestinal development, nutrient utilization, immune system, and the homeostasis of gut microbiota [24]. Two typical parameters, $\mathrm{VH}$ and $\mathrm{CD}$, are always used to reflect the intestinal morphological development of animals. In addition, the greater value of VH/CD suggests excellent intestinal development and better ability to digest and absorb nutrients [25]. In our study, we firstly found that dietary YH supplementation at the level ranged from 100 to 150 $\mathrm{mg} / \mathrm{kg}$ improved jejunal $\mathrm{VH}$ and $\mathrm{VH} / \mathrm{CD}$ whereas decreased $\mathrm{CD}$ of broilers, and $100 \mathrm{mg} / \mathrm{kg}$ additional level presented better effects than $150 \mathrm{mg} / \mathrm{kg}$. These findings suggested that $\mathrm{YH}$ addition efficiently improved intestinal morphology of broilers. Similar with our results, Fu et al [26] presented that supplementing $\mathrm{YH}$ increased jejunal $\mathrm{VH}$ and $\mathrm{VH} / \mathrm{CD}$ as well as gut development-related genes expression to maintain intestinal integrity in weaned piglets. A previous study showed that dietary Saccharomyces cerevisiae hydrolysate increased the villus length and muscle thickness in the foregut and midgut as well as intestinal microvillus length and density in aquatic animals, thus increasing the intestinal absorptive surface area and improving nutrient capture [6], which might help to improve feed efficiency. Besides, other yeast-derived additives including live yeast and yeast culture also showed positive effects on intestinal morphology [13,27]. The beneficial effects of YH on intestinal morphology might in connection with its abundant nucleotides. It has been shown that nucleotides could promote intestinal development though facilitating the proliferation and maturation of intestinal cells [28]. Also, yeast cell wall components including MOS or $\beta$-glucan could dampen the pathogens (Salmonella, Escherichia coli, and Listeria) from adhering and colonizating in the intestine as well as interact with immune cells so as to neutralize intestinal villi atrophy due to inflammation [29,30]. Relevant experimental results reported that supplementing MOS and $\beta$-glucan enhanced small intestinal goblet cells count, increase $\mathrm{VH}$ and $\mathrm{VH} / \mathrm{CD}$ but decreased $\mathrm{CD}$ in animals, thus improving intestinal morphology as well as benefiting intestinal health and growth performance ultimately $[31,32]$. Thus, the beneficial effects of supplementing $\mathrm{YH}$ might be related to the abundant bioactive agents to providing a healthy enteric environment for broilers.

The DAO expressed in intestinal mucosa upper chorial cells will release into blood circulation from the villus tips when intestinal barrier is impaired. Thus, serum DAO activity could be deemed as a blood marker to monitor the extent of intestinal damage [1]. Available evidence has showed that the damaged intestinal mucosa was always accompanied by an increased serum DAO activity $[1,13]$. In this study, dietary YH supplementation at the level ranged from 50 to $150 \mathrm{mg} / \mathrm{kg}$ decreased serum DAO activity in broilers, which suggested a decrease of intestinal permeability. Consistently, supplementing $\mathrm{YH}$ and other yeast-derived additives decreased serum endotoxin content and DAO activity in various animal studies $[13,26,27]$. The intestinal permeability is correlated with its intact mechanical barrier. Tight junction proteins act as a fence to prevent the translocation of macromolecular including harmful pathogenic bacteria and toxic substances by forming a paracellular permeability barrier. ZO-1, a crucial intestinal tight junction protein, which effectively defends against exogenous infections, thus maintaining the integrity of the intestinal barrier. Evidence has indicated that dietary YH supplementation protected intestinal mechanical barrier though up-regulating jejunal ZO-1 mRNA expression level in piglets [26]. Besides, Ducray et al [33] found that supplementing yeast fermentate prebiotic reversed the decreases of intestinal tight junction proteins expression including ZO-1, occludin (OCLN), and claudin (CLDN) in rats during heat stress though modulating the gut microbiota. Similarly, the enhanced jejunal ZO-1 gene expression level by $\mathrm{YH}$ addition in the present study suggested the positive effects of $\mathrm{YH}$ on intestinal barrier function in broilers. Mucin 2 is the major component of the chemical barrier, which protects against the invasion of bacteria and pathogen as well as promotes intestinal restitution [34]. In the present study, jejunal MUC2 gene expression was decreased by $\mathrm{YH}$ addition. Zhang et al [35] and Chen et al [36] showed that the MUC2 mRNA expression level was elevated in broilers challenged with lipopolysaccharide. The reason might be the existence of a kappa $\mathrm{B}$ site in the 5'-flanking region of the MUC2 gene which activates $M U C 2$ gene to transcription level and enhances pro-inflammatory cytokine contents [37]. Various active substances contained in $\mathrm{YH}$ might be contribute to the improved intestinal barrier function. It has been reported that dietary prebiotics and probiotic could up-regulate intestinal tight junction proteins expression in animals [38]. Supplementing yeast nucleotide up-regulated ileal $\mathrm{ZO}-1$ and $C L D N$ genes expression to increase the integrality of mechanical barrier in chickens [34]. Wang et al [13] and Han et al [29] demonstrated that dietary addition with yeast cell wall components, MOS and $\beta$-glucan, could up-regulate intestinal tight junction proteins expression, thus decreasing the in- 
testinal permeability and improving the intestinal structural integrity in animals. Recent research indicated that the enhanced intestinal barrier function might be related to improved intestinal morphological structure [13], which coincided with our experimental results. These findings suggested that supplementing YH confers a beneficial effect on intestinal mucosal function and intestinal environment of broilers.

The control of intestinal inflammation is the key to healthy breeding. In the present study, dietary YH supplementation improved intestinal anti-inflammatory function of broilers, as evidenced by the increased IL-10 and reduced TNF- $\alpha$ concentration in the jejunum of broilers. Interleukin 10, secreted by activated macrophages, is a key cytokine to restrain the excessive production of pro-inflammatory cytokines and maintain immune balance of the body [13]. Conversely, TNF- $\alpha$ is a pro-inflammatory cytokine mainly produced by macrophages and monocytes, which level increases in many pathological conditions $[5,6]$. An article reported that lower serum immunoglobulins $\mathrm{A}$ and $\mathrm{E}$ levels and higher intestinal TNF- $\alpha$ level were observed in $I L-10$ gene knockout mice compared with the mice without knockout [39]. Consistent with our results, dietary $\mathrm{YH}$ addition elevated serum IL-10 level but decreased IL- $1 \beta$ and TNF- $\alpha$ concentrations in pigs $[16,26]$. Waititu et al $[4]$ indicated that yeast extract addition neutralized the increase of serum TNF- $\alpha$ and the decrease of IL-10 cytokines levels in weaned pigs challenged with Escherichia coli lipopolysaccharide, meanwhile, enhancing IL- 10 but reducing TNF- $\alpha$ and $I L-1 \beta$ genes expression. From gene transcription levels, the jejunal $I L-6,1 L-1 \beta, T N F-\alpha$, $N F-\kappa B$, and $M y D 88$ genes expression were decreased while that of IL-10 was enhanced by YH supplementation in this study. IL-6, as a crucial mediator, could increase endothelial permeability by changing the ultrastructural of ZO-1 [40]. Additionally, IL- $1 \beta$, IL- 6 and TNF- $\alpha$ are essential cytokines to initiate inflammatory responses. Song et al [40] reported that NF- $\kappa$ B plays a key role in inducing intestinal inflammation via synthesizing and releasing pro-inflammatory cytokines including IL-6, $1 \mathrm{~L}-1 \beta$, and TNF- $\alpha$. Similarly, MyD88 exerts effects on toll-like receptor signal transduction pathways to induce various inflammatory responses and diseases. In coincidence with our results, dietary YH reduced intestinal TNF- $\alpha, 1 \mathrm{~L}-1 \beta$, TLR4, and alkaline phosphatase genes expression to dampen the inflammatory response in different animals $[6,26]$. Evidence has been proposed that yeast culture addition down-regulated pro-inflammatory cytokines expression via restraining the pathway related to NF- $\mathrm{KB}$ in animals $[3,27,41]$. Also, Yuan et al [42] reported that supplementing a yeast-derived additive modulated the uterine inflammatory signals by decreasing uterine IL- 6 mRNA expression as well as enhancing neutrophil myeloperoxidase and neutrophil elastase genes expression in transition dairy cows to reduce the incidence of subclinical endome- tritis. The active components in $\mathrm{YH}$ might be responsible for its anti-inflammatory function. Previous research indicated that the presence of Saccharomyces cerevisiae var. boulardii reduced intestinal inflammation and colonization by Candida albicans [43]. Dietary yeast nucleotides modulated gastrointestinal function and optimized intestinal microbiota to improve immunity function of intestinal mucosa [34]. The two main components in yeast cell wall, MOS and $\beta$-glucans, have also been shown to have beneficial anti-inflammatory effects. Dietary MOS supplementation enhanced serum IL-10 concentration but reduced IL-2, IL4 , and IFN- $\gamma$ cytokines levels as well as intestinal TLR2, TLR4, $I L-8$, and $N F-\kappa B$ genes expression to suppress intestinal and systemic inflammation in sows [15]. An in vitro study indicated that yeast cell wall and $\beta$-glucans could activate CD22 receptors, which regulate the mitogen-activated protein kinase pathway and negatively regulate $\mathrm{B}$ cell activation to control the inflammatory response [44]. Likewise, it has been reported that $\beta$-glucans act as immunomodulators to weaken the development of inflammatory disease [45]. However, due to the intricacy nutrient composition in $\mathrm{YH}$ and the unclear mechanism by which YH improves the anti-inflammatory function of broiler chickens, further research on $\mathrm{YH}$ is still needed.

\section{CONCLUSION}

It can be concluded that, the addition of 100 to $150 \mathrm{mg} / \mathrm{kg}$ $\mathrm{YH}$ generally improved intestinal morphology, barrier and anti-inflammatory functions whereas decreased intestinal permeability of broilers.

\section{CONFLICT OF INTEREST}

We certify that there is no conflict of interest with any financial organization regarding the material discussed in the manuscript.

\section{FUNDING}

This research was supported by the Natural Key Research and Development Program of China (2018YFD0501101).

\section{ACKNOWLEDGMENTS}

The technical assistance of colleagues in our laboratories is gratefully acknowledged.

\section{REFERENCES}

1. Zhang H, Chen YN, Chen YP, et al. Dietary pterostilbene supplementation attenuates intestinal damage and immu- 
nological stress of broiler chickens challenged with lipopolysaccharide. J Anim Sci 2020;98:skz373. https://doi.org/10. 1093/jas/skz373

2. Zhang YY, Liu YS, Li JL, et al. Dietary corn resistant starch regulates intestinal morphology and barrier functions by activating the Notch signaling pathway of broilers. AsianAustralas J Anim Sci 2020;33:2008-20. https://doi.org/10. 5713/ajas.19.0967

3. Bu XY, Huang JS, Tao SQ, et al. Yeast cultures alleviate gossypol induced inflammatory response in liver tissue of Ussuri catfish (Pseudobagrus ussuriensis). Aquaculture 2020;518:734828. https://doi.org/10.1016/j.aquaculture.2019.734828

4. Waititu SM, Yin F, Patterson R, Rodriguez-Lecompte JC, Nyachoti CM. Short-term effect of supplemental yeast extract without or with feed enzymes on growth performance, immune status and gut structure of weaned pigs challenged with Escherichia coli lipopolysaccharide. J Anim Sci Biotechnol 2016;7:64. https://doi.org/10.1186/s40104-016-0125-5

5. Waititu SM, Yin F, Patterson R, Yitbarek A, RodriguezLecompte JC, Nyachoti CM. Dietary supplementation with a nucleotide-rich yeast extract modulates gut immune response and microflora in weaned pigs in response to a sanitary challenge. Animal 2017;11:2156-64. https://doi.org/10.1017/S17 51731117001276

6. Yuan XY, Jiang GZ, Wang CC, et al. Effects of partial replacement of fish meal by yeast hydrolysate on antioxidant capability, intestinal morphology, and inflammation-related gene expression of juvenile Jian carp (Cyprinus carpio var. Jian). Fish Physiol Biochem 2019;45:187-97. https://doi.org/ 10.1007/s10695-018-0552-7

7. Zhang JY, Park JW, Kim IH. Effect of supplementation with brewer's yeast hydrolysate on growth performance, nutrients digestibility, blood profiles and meat quality in growing to finishing pigs. Asian-Australas J Anim Sci 2019;32:1565-72. https://doi.org/10.5713/ajas.18.0837

8. Bi S, Zhang J, Qu Y, Zhou B, He X, Ni J. Yeast cell wall product enhanced intestinal IgA response and changed cecum microflora species after oral vaccination in chickens. Poult Sci 2020;99:6576-85. https://doi.org/10.1016/j.psj.2020.09.075

9. Ma J, Shah AM, Shao YQ, Wang ZS, Zou HW, Kang K. Dietary supplementation of yeast cell wall improves the gastrointestinal development of weaned calves. Anim Nutr 2020;6:50712. https://doi.org/10.1016/j.aninu.2020.06.003

10. Ahiwe EU, Abdallh ME, Chang'A EP, et al. Influence of dietary supplementation of autolyzed whole yeast and yeast cell wall products on broiler chickens. Asian-Australas J Anim Sci 2020;33:579-87. https://doi.org/10.5713/ajas.19.0220

11. Bilal RM, Hassan F, Saeed M, et al. Prospects of yeast based feed additives in poultry nutrition: Potential effects and applications. Indian J Anim Sci 2020;90:495-505.

12. Yousefi S, Monsef Shokri MM, Allaf Noveirian HA, Hoseinifar SH. Effects of dietary yeast cell wall on biochemical indices, serum and skin mucus immune responses, oxidative status and resistance against Aeromonas hydrophila in juvenile Persian sturgeon (Acipenser persicus). Fish Shellfish Immunol 2020;106:464-72. https://doi.org/10.1016/j.fsi.2020.08.007

13. Wang WW, Li Z, Han QQ, Guo YM, Zhang B, D'Inca R. Dietary live yeast and mannan-oligosaccharide supplementation attenuate intestinal inflammation and barrier dysfunction induced by Escherichia coli in broilers. Br J Nutr 2016; 116:1878-88. https://doi.org/10.1017/S0007114516004116

14. Chaiyasut C, Pengkumsri N, SivamaruthiI BS, et al. Extraction of $\beta$-glucan of Hericium erinaceus, Avena sativa L., and Saccharomyces cerevisiae and in vivo evaluation of their immunomodulatory effects. Food Sci Technol 2018;38(Suppl 1): 138-46. https://doi.org/10.1590/fst.18217

15. Duan XD, Tian G, Chen DW, et al. Mannan oligosaccharide supplementation in diets of sow and (or) their offspring improved immunity and regulated intestinal bacteria in piglet. J Anim Sci 2019;97:4548-56. https://doi.org/10.1093/jas/skz318

16. Fu RQ, Chen DW, Tian G, et al. Effect of dietary supplementation of Bacillus coagulans or yeast hydrolysates on growth performance, antioxidant activity, cytokines and intestinal microflora of growing-finishing pigs. Anim Nutr 2019;5: 366-72. https://doi.org/10.1016/j.aninu.2019.06.003

17. Jin M, Xiong J, Zhou Q, Yuan Y, Wang X, Sun P. Dietary yeast hydrolysate and brewer's yeast supplementation could enhance growth performance, innate immunity capacity and ammonia nitrogen stress resistance ability of Pacific white shrimp (Litopenaeus vannamei). Fish Shellfish Immunol 2018;82:121-9. https://doi.org/10.1016/j.fsi.2018.08.020

18. Timothée Andriamialinirina HJ, Irm M, Taj S, Lou JH, Jin M, Zhou Q. The effects of dietary yeast hydrolysate on growth, hematology, antioxidant enzyme activities and non-specific immunity of juvenile Nile tilapia, Oreochromis niloticus. Fish Shellfish Immunol 2020;101:168-75. https://doi.org/10.1016/j. fsi.2020.03.037

19. Wang T, Cheng K, Yu CY, Tong YC, Yang ZB, Wang T. Effects of yeast hydrolysate on growth performance, serum parameters, carcass traits, meat quality and antioxidant status of broiler chickens. J Sci Food Agric 2022;102:575-83. https://doi.org/ 10.1002/jsfa. 11386

20. Wang T, Cheng K, Yu CY, et al. Effects of a yeast-derived product on growth performance, antioxidant capacity, and immune function of broilers. Poult Sci 2021;100:101343. https://doi.org/10.1016/j.psj.2021.101343

21. National Research Council. Nutrient requirements of poultry. 9th revised. edn. Washington, DC, USA: National Academy Press; 1994.

22. Livak KJ, Schmittgen TD. Analysis of relative gene expression data using real-time quantitative PCR and the 2(-Delta Delta C(T)) method. Methods 2001;25:402-8. https://doi.org/10. 1006/meth.2001.1262

23. SAS Institute. Users guide. Release 8.1 ed. Cary, NC, USA: 
SAS Institute Inc.; 2000.

24. Zhang C, Wang C, Chen KK, Zhao XH, Geng ZY. Effect of L-theanine on growth performance, intestinal development and health, and peptide and amino acid transporters expression of broilers. J Sci Food Agric 2020;100:1718-25. https://doi. org/10.1002/jsfa.10192

25. Yang L, Liu G, Lian KX, et al. Dietary leonurine hydrochloride supplementation attenuates lipopolysaccharide challengeinduced intestinal inflammation and barrier dysfunction by inhibiting the NF- $\mathrm{kB} / \mathrm{MAPK}$ signaling pathway in broilers. J Anim Sci 2019;97:1679-92. https://doi.org/10.1093/jas/skz078

26. Fu RQ, Liang C, Chen DW, et al. Effects of dietary Bacillus coagulans and yeast hydrolysate supplementation on growth performance, immune response and intestinal barrier function in weaned piglets. J Anim Physiol Anim Nutr 2021;105:898907. https://doi.org/10.1111/jpn.13529

27. Wang SQ, Zhu SL, Zhang JJ, et al. Supplementation with yeast culture improves the integrity of intestinal tight junction proteins via NOD1/NF- $\kappa \mathrm{B}$ P65 pathway in weaned piglets and $\mathrm{H} 2 \mathrm{O} 2$-challenged IPEC-J2 cells. J Funct Foods 2020; 72:104058. https://doi.org/10.1016/j.jff.2020.104058

28. Ortega Á, Gil Á, Sánchez- Pozo A. Exogenous nucleosides modulate expression and activity of transcription factors in Caco-2 cells. J Nutr Biochem 2011;22:595-604. https://doi. org/10.1016/j.jnutbio.2010.05.003

29. Han FF, Fan HX, Yao M, Yang SS, Han JZ. Oral administration of yeast $\beta$-glucan ameliorates inflammation and intestinal barrier in dextran sodium sulfate- induced acute colitis. J Funct Foods 2017;35:115-26. https://doi.org/10.1016/j.jff. 2017.05.036

30. Kim K, Ehrlich A, Perng V, et al. Algae-derived $\beta$-glucan enhanced gut health and immune responses of weaned pigs experimentally infected with a pathogenic E. coli. Anim Feed Sci Technol 2019;248:114-25. https://doi.org/10.1016/j. anifeedsci.2018.12.004

31. Kazempour F, Shargh MS, Jahanian R, Hassani S. Effect of dietary beta-glucan supplementation on growth performance, carcass characteristics and gut morphology in broiler chicks fed diets containing different theronine levels. Anim Feed Sci Technol 2017;234:186-94. https://doi.org/10.1016/j.ani feedsci.2017.07.015

32. Agazzi A, Perricone V, Omodei Zorini FO, et al. Dietary mannan oligosaccharides modulate gut inflammatory response and improve duodenal villi height in post-weaning piglets improving feed efficiency. Animals 2020;10:1283. https://doi.org/10.3390/ani10081283

33. Ducray HAG, Globa L, Pustovyy O, Morrison E, Vodyanoy V, Sorokulova I. Yeast fermentate prebiotic improves intestinal barrier integrity during heat stress by modulation of the gut microbiota in rats. J Appl Microbiol 2019;127:1192-206. https:// doi.org/10.1111/jam.14361

34. Wu C, Yang Z, Song C, et al. Effects of dietary yeast nucleotides supplementation on intestinal barrier function, intestinal microbiota, and humoral immunity in specific pathogenfree chickens. Poult Sci 2018;97:3837-46. https:/doi.org/ 10.3382/ps/pey268

35. Zhang Q, Chen X, Eicher SD, Ajuwon KM, Applegate TJ. Effect of threonine on secretory immune system using a chicken intestinal ex vivo model with lipopolysaccharide challenge. Poult Sci 2017;96:3043-51. https://doi.org/10. 3382/ps/pex111

36. Chen YP, Zhang H, Cheng YF, Li Y, Wen C, Zhou YM. Dietary L-threonine supplementation attenuates lipopolysaccharideinduced inflammatory responses and intestinal barrier damage of broiler chickens at an early age. Br J Nutr 2018;119:125462. https://doi.org/10.1017/S0007114518000740

37. Andrianifahanana M, Moniaux N, Batra SK. Regulation of mucin expression: mechanistic aspects and implications for cancer and inflammatory diseases. Biochim Biophys Acta Rev Cancer 2006;1765:189-222. https://doi.org/10.1016/j. bbcan.2006.01.002

38. Alizadeh A, Akbari P, Difilippo E, et al. The piglet as a model for studying dietary components in infant diets: effects of galacto-oligosaccharides on intestinal functions. Br J Nutr 2016;115:605-18. https://doi.org/10.1017/S0007114515004997

39. Ye MB, Bak JP, An CS, et al. Dietary beta-glucan regulates the levels of inflammatory factors, inflammatory cytokines, and immunoglobulins in interleukin-10 knockout mice. J Med Food 2011;14:468-74. https://doi.org/10.1089/jmf.2010. 1197

40. Song ZH, Cheng K, Zhang LL, Wang T. Dietary supplementation of enzymatically treated Artemisia annua could alleviate the intestinal inflammatory response in heat-stressed broilers. J Therm Biol 2017;69:184-90. https://doi.org/10.1016/j.jtherbio. 2017.07.015

41. Bu XY, Lian XQ, Wang Y, et al. Dietary yeast culture modulates immune response related to TLR2-MyD88-NF- $\kappa$ B signaling pathway, antioxidant capability and disease resistance against Aeromonas hydrophila for Ussuri catfish (Pseudobagrus ussuriensis). Fish Shellfish Immunol 2019;84:711-8. https:// doi.org/10.1016/j.fsi.2018.10.049

42. Yuan K, Mendonça LGD, Hulbert LE, et al. Yeast product supplementation modulated humoral and mucosal immunity and uterine inflammatory signals in transition dairy cows. J Dairy Sci 2015;98:3236-46. https://doi.org/10.3168/jds.20148469

43. Jawhara S, Habib K, Maggiotto F, et al. Modulation of intestinal inflammation by yeasts and cell wall extracts: strain dependence and unexpected anti-Inflammatory role of glucan fractions. PLoS One 2012;7:e40648. https://doi.org/10.1371/ journal.pone.0040648

44. Penney J, Lu Y, Pan B, Feng Y, Walk C, Li J. Pure yeast betaglucan and two types of yeast cell wall extracts enhance cell migration in porcine intestine model. J Funct Foods 2019;59: 
129-37. https://doi.org/10.1016/j.jff.2019.05.037

45. Choi EY, Lee SS, Hyeon JY, et al. Effects of beta-glucan on the release of nitric oxide by macrophages stimulated with lipopolysaccharide. Asian-Australas J Anim Sci 2016;29: 1664-74. https://doi.org/10.5713/ajas.16.0418 